\title{
LATE WISCONSIN GLACIATION OF TASMANIA
}

\author{
by Eric A. Colhoun, David Hannan and Kevin Kiernan
}

(with two tables, four text-figures and one plate)

Colmoun, E.A., Hannan, D. \& Kiernan, K., 1996 (xi): Late Wisconsin glaciation of Tasmania. In Banks, M. R. \& Brown, M.F. (Eds): CLIMATIC SUCCESSION AND GLACIAL HISTORY OF THE SOUTHERN HEMISPHERE OVER THE LAST FIVE MILLION YEARS. Pap. Proc. R. Soc. Tasm. 130(2): 33-45. https://doi.org/10.26749/rstpp.130.2.33 ISSN 0080-4703. Department of Geography, University of Newcastle, Callaghan, NSW, Australia 2308 (EAC); Department of Physical Sciences, University of Tasmania at Launceston, Tasmania, Australia 7250 (DH); Forest Practices Board of Tasmania, 30 Patrick Street, Hobart, Tasmania, Australia 7000 (KK).

During the Late Wisconsin, icecap and outlet glacier systems developed on the West Coast Range and on the Central Plateau of Tasmania. Local cirque and valley glaciers occurred in many other mountain areas of southwestern Tasmania. Criteria are outlined that enable Late Wisconsin and older glacial landforms and deposits to be distinguished. Radiocarbon dates show Late Wisconsin ice developed after 26-25 ka BP, attained its maximum extent c. $19 \mathrm{ka} \mathrm{BP}$, and disappeared from the highest cirques before $10 \mathrm{ka}$ BP. Important Late Wisconsin age glacial landforms and deposits of the West Coast Range, north-central and south-central Tasmania are described. Late Wisconsin ice was less extensive than ice formed during middle and earlier Pleistocene glaciations. Late Wisconsin snowline altitudes, glaciological conditions and palaeoclimatic conditions are outlined.

Key Words: glaciation, Tasmania, Late Wisconsin, snowline altitude, palaeoclimate.

\section{INTRODUCTION}

An answer is still sought to the question of the extent of glacial ice during the maximum of the last glaciation (Derbyshire 1972: 86).

Evidence for development of Pleistocene ice in Tasmania was first noted in 1859-60 by Charles Gould in the Cuvier Valley near Lake St Clair (Banks et al. 1987). Subsequently, numerous geologists recorded evidence for ice in the Central Plateau, the West Coast Range and in mountains throughout southwestern Tasmania. Most data related to landforms of glacial erosion with only limited recognition of glacial deposits; e.g. the map and description of erosional forms on the Central Plateau by Jennings \& Ahmad (1957) and the description of glacial deposits near Queenstown by Gregory (1904). Only Lewis (1945) integrated his results in a sequence-model of glaciations that had affected western Tasmania. Lewis suggested three stages: the first characterised by an extensive ice sheet over much of western Tasmania; the second by cirque and valley glaciers; the third by cirque glaciers only. None of the deposits relating to the three stages of glaciation were dated. Gill (1956) obtained a radiocarbon date of $26480 \pm 800 \mathrm{yr} \mathrm{BP}$ (W-323) on wood from sands and gravels at Linda. The deposits were interpreted as glacial in origin, and a Late Wisconsin age was suggested for the glaciation. Jennings \& Banks (1958) considered there was not stratigraphic evidence for three glacial stages in Tasmania and, when Banks \& Ahmad (1959) showed that the deposits of Lewis's oldest glaciation at Malanna were fluvial and lacustrine, the hypothesis of multiple glaciation became seriously questioned.

The evidence for glaciation in Tasmania remained fragmentary until Derbyshire et al. (1965) compiled $A$ Glacial Map of Tasmania from glacial landforms observable on the first aerial photograph coverage. The map indicated the extent to which Tasmania had been glaciated, but it did not differentiate Late Wisconsin from older glacial landforms.
During the late 1970s, 1980s and early 1990s, field mapping and stratigraphic investigations demonstrated that Tasmania had a complex history of multiple glaciation, most of which pre-dated the Late Wisconsin (Kiernan 1982, 1983a, 1989, 1991, 1995, Colhoun 1985, Augustinus \& Colhoun 1986, Hannan \& Colhoun 1987, Barbetti \& Colhoun 1988, Kiernan \& Hannan 1991, Fitzsimons \& Colhoun 1991, Fitzsimons et al. 1992). A number of criteria were used to separate Late Wisconsin from older glacial landforms and deposits. The limits of Late Wisconsin ice were first recorded for the West Coast Range system (Colhoun 1985) and then extended to the northwestern Central Plateau and Mersey Valley (Hannan \& Colhoun 1987), and the southern Central Highlands and Lake St

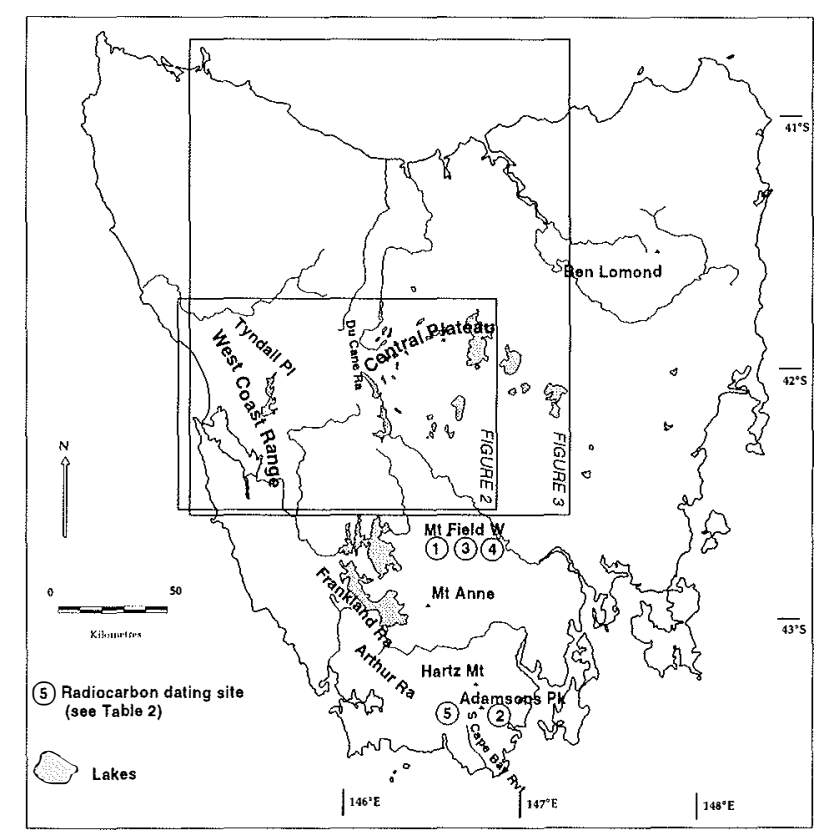

FIG. 1 - Tasmania, showing locations of figures 2 and 3, and radiocarbon dates not shown on the larger figures. 


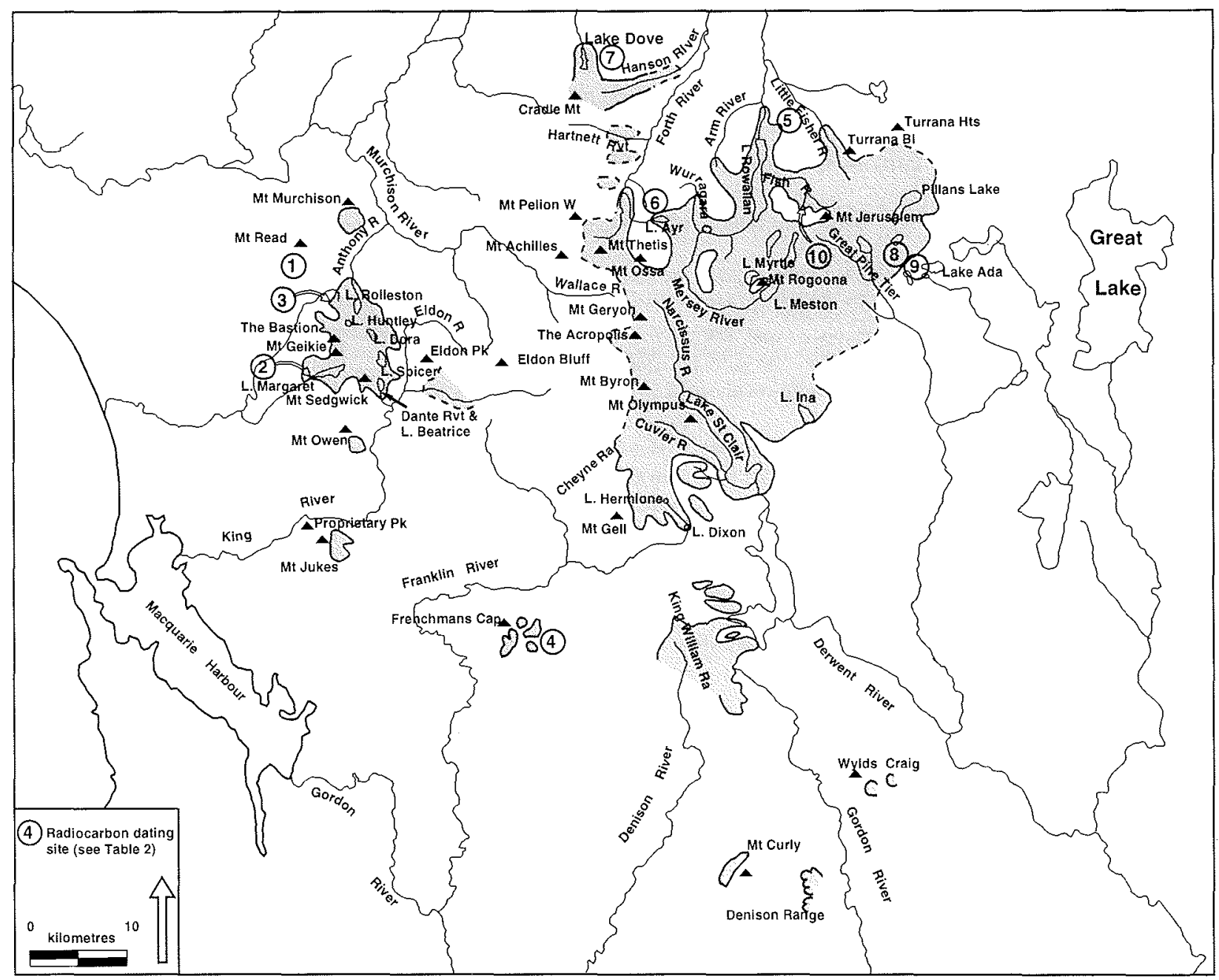

FIG. 2 - The major areas of glacier ice during the Late Wisconsin.

Clair area (Kiernan 1990). The Late Wisconsin ice limits are not yet known in all parts of Tasmania, e.g. the ice limit shown in figure 2 for the southeastern Central Plateau is approximate, and only some of the mountain areas of southwestern Tasmania have been mapped recently. Nevertheless, many new data have been obtained for the extent of Late Wisconsin ice, which allow revision of the small-scale map of Davies (1967).

This paper illustrates, with examples, criteria used to separate Late Wisconsin from older glacial landforms and deposits. It describes evidence for the Late Wisconsin ice limits in the West Coast Range, north-central and southcentral parts of highland Tasmania (figs 1,2), and discusses the Late Wisconsin glacial environment. The greater extent of middle and early Pleistocene ice is shown in figure 3 .

\section{SEPARATION OF LATE WISCONSIN FROM OLDER GLACIAL LANDFORMS AND DEPOSITS}

The criteria used to separate Late Wisconsin and older glacial landforms and deposits are indicated in table 1.

Throughout the mountains and plateaux of Tasmania landscapes glaciated during the Late Wisconsin can be recognised by ice-scouring in the source areas, and deposition of end moraines and outwash terraces at the ice limits. Ice developed on the high western parts of the Central Plateau, on the small plateau-summit of the Tyndall Range (pl. 1A), and in cirques and valley heads, where snow borne by westerly and southwesterly winds accumulated leeward of watershed-ridges.

The source areas are distinguished by glacially abraded rock surfaces, scraped almost bare of soil and debris. In addition, ice-plucking has emphasised rock structures, as shown by the NW-SE and NE-SW joint-controlled development of the rock-basin lakes of the Central Plateau (Jennings \& Ahmad 1957). Quartzites and other siliceous rocks in the western mountains exhibit numerous striations, which are rare on the dolerites of the Central Plateau due to postglacial chemical weathering.

The glaciers that flowed from the Tyndall Range and Central Plateau through deep valleys terminated in conspicuous end moraines with steep ice proximal/contact slopes, as did cirque and valley glaciers in the mountains of southwestern Tasmania. Most end moraines are $10-100 \mathrm{~m}$ in height, and some form impressive scenic features. The highest is the Hamilton End Moraine that has $300 \mathrm{~m}$ of relief, though it was deposited at the edge of a bedrock shelf which accounts for about half the relief (pl. 1B). Outside the Late Wisconsin ice limits, moraines formed 


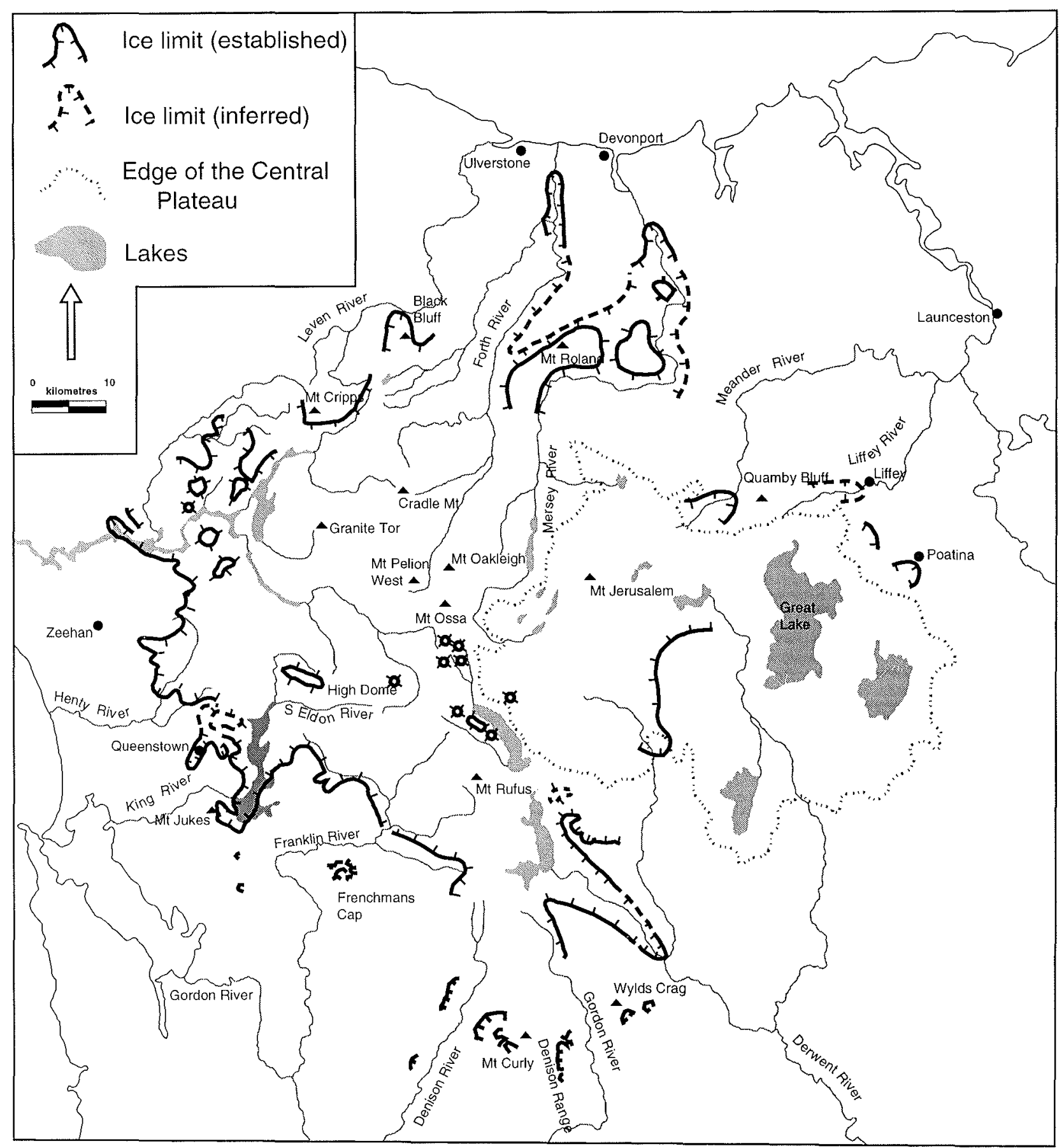

FIG. 3 - The maximum extent of Pleistocene ice in western and central Tasmania.

during middle and early Pleistocene glaciations do not exhibit steep ice-contact slopes, but have more rounded forms. Their slopes are dissected by minor, water-cut valleys. Outwash terraces or fans, undissected except for incision of the main postglacial river courses, extend down-valley from many of the Late Wisconsin end moraines. The terraces consist of bedded gravel and sand, and may extend several kilometres before ending, usually at a constriction in valley cross-profile.

Outside the end moraines and above the lateral moraines of both Late Wisconsin and earlier glaciations, the plateaux are covered with rock debris. The debris was formed from weathered regolith of Jurassic dolerite that contained many corestones, and from bedrock by periglacial processes.
Though largely undated, the rock debris accumulated over periods much longer than single glacial events. Thick periglacial debris is never found within Late Wisconsin ice limits. The development of extensive blockfields and blockstreams on Ben Lomond, in northeastern Tasmania, was used by Caine (1983) to assign glaciation of the plateau to a pre-Wisconsin stage, but the extent of such glaciation is not known.

Between the zone dominated by glacial erosion and the end moraines, Late Wisconsin till and associated deposits mantle the valley floors and lower slopes, often discontinuously. The till is variable in thickness and consists of boulders and cobbles supported in an unweathered, compact matrix, derived mainly from local rocks. (pl. 1C). 
Late Wisconsin forms and deposits Pre-Late Wisconsin forms and deposits

\section{Landforms}

Cirque headwalls, valley sides and plateau surfaces ice-scoured with rock basin lakes. Virtually no soil and little rock detritus Large,sharp-crested, undissected end and lateral moraines

Extensive, undissected outwash terraces

Deposits

Geographically the innermost drift sheet

Igneous clasts in till and outwash not weathered below shallow soil prpfile of $<1-1.5 \mathrm{~m}$ depth

Only moderate iron and manganese staining of deposits

Only rare, poorly developed, iron-pans formed below soil

Dating

Mean weathering rind thickness of subsurface Jurassic dolerite clasts usually $<1 \mathrm{~mm}$ at $300 \mathrm{~mm}$ depth (max. $5 \mathrm{~mm}$ )

Younger and contemporary organic materials datable by radiocarbon
Moraines have rounded crests and are dissected by minor channels

Extensive outwash terraces, little to moderately dissected by minor streams

Extensive boulder fields, blockstreams and tor-forms on high plateaux, with screes and solifluction deposits on slopes

Occur geographically outside the Late Wisconsin ice limits

Igneous clasts in till and outwash moderately to strongly weathered; soil profiles may be $>1-1.5 \mathrm{~m}$ in depth

Moderate to very strong iron/manganese staining of deposits. Reduced specific gravity of volcanic clasts

Thick and multiple iron-pans may be formed below soil

Weathering rinds on subsurface Jurassic dolerite clasts up to $200 \mathrm{~mm}$ thick

Associated organic materials beyond radiocarbon range. Wood in interglacial deposits assayed by amino-acid method

Oldest glacial deposits have reversed magnetisation
Few easily recognised erratics occur in northern and southcentral Tasmania, but in the glacial deposits of western Tasmania igneous erratics are common. Only rarely are stratigraphic contacts found that show Late Wisconsin till overlying till of an older glaciation. The best example occurs in the upper Arm Valley of northern Tasmania, where Late Wisconsin Rowallan Till overlies Arm Till of the preceding glaciation (probably of Isotope Stage 6 (pl. 1D). The Hamilton End Moraine (pl. 1B) also shows complexity of stratigraphic development. Till containing strongly weathered clasts of the Mt Read Volcanic Group occurs on the surface of Boulder Hill in the centre of the moraine arc, but the major part of the moraine formed of Owen conglomerate boulders is of Late Wisconsin age (E.A. Colhoun \& P. Augustinus, pers. obs.).

The Late Wisconsin till, ice-contact and outwash gravel and sand deposits can be distinguished from older glacial deposits by the relative lack of weathering of igneous clasts (see dating, table 1). In addition, Late Wisconsin age deposits do not have thick iron-pan horizons, and iron and manganese oxide staining does not extend below the soil profile. At freely drained sites, postglacial soil development is minimal, and the $C_{\text {ox }}$ horizon does not exceed $1-1.5 \mathrm{~m}$ depth (Hammond 1985). Older glacial deposits are characterised by strong weathering of igneous clasts, ironpan formation, iron and manganese oxide precipitation, and deep soil formation on freely drained and uneroded sites.

Dating and age differentiation of Late Wisconsin from older glacial deposits have employed several methods. Kiernan (1983a) used mean thickness of weathering rinds on erratic dolerite clasts in tills of the central West Coast Range to assess the age of deposition. He showed that, in Late Wisconsin tills, weathering rinds on dolerite clasts at $300 \mathrm{~mm}$ depth were $<1 \mathrm{~mm}$ in mean thickness, and that two older tills gave mean weathering-rind thicknesses of $4.9 \pm 2.8 \mathrm{~mm}$ and $55.8 \pm 21.6 \mathrm{~mm}$ (fig. 4). Augustinus \& Colhoun (1986) also showed the effects of increased weathering of igneous clasts with age by demonstrating that volcanic clasts of the Mt Read Group have reduced specific gravities in stratigraphically older tills. These studies, combined with the work of Bowden (1974) and Colhoun (1985), convincingly demonstrated pre-Late Wisconsin age multiple glaciation of western Tasmania, as hypothesised by Lewis (1945). Kiernan used a linear relationship, between weathering rind thickness and time, to suggest that the oldest glacial deposits in western Tasmania were more than 600000 years old. Kiernan's method has also been applied to the glacial deposits of north-central and south-central Tasmania. In both regions, the results show that Late Wisconsin glacial deposits are little weathered and older deposits are highly weathered (Hannan \& Colhoun 1987, Kiernan 1992).

Radiocarbon age assay of the Late Wisconsin glacial stade in Tasmania has been obtained by dating organicrich deposits in three situations. Firstly, dates have been obtained from organic deposits in lakes and bogs outside the inferred Late Wisconsin ice limits. Several of these sites have pollen/vegetation histories that allow estimation of the date of commencement of the last cold stade. Secondly, an important section occurs at Dante Rivulet which has permitted close dating of the maximum advance of Late 

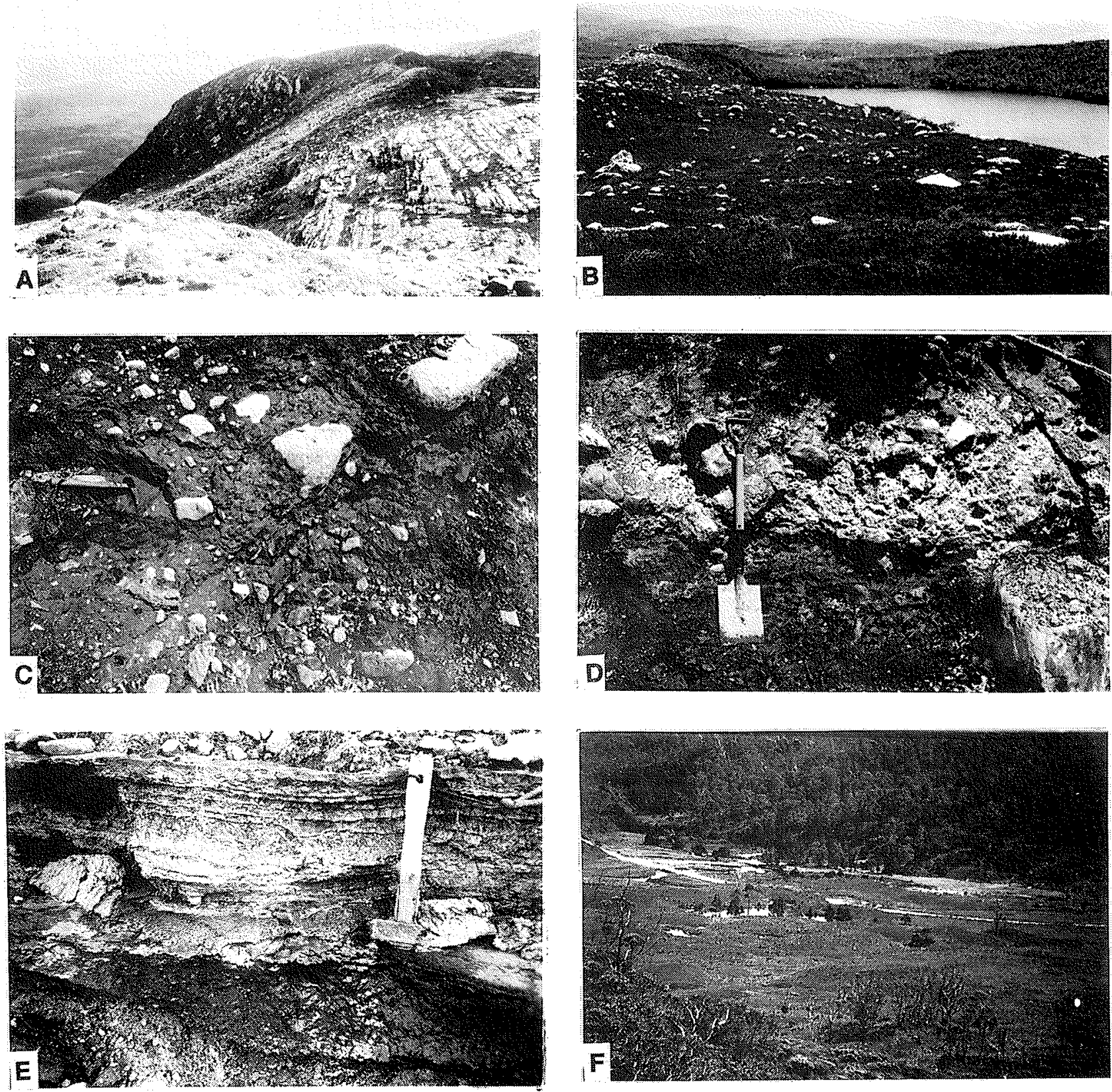

PLATE I

(A) Ice smoothed conglomerate and sandstone of the Tyndall Plateau with end moraine on the plateau edge, looking north from the Bastion on Mt Geikie (Photo A.Bowden, 1974). (B) The Hamilton End Moraine surrounding Basin Lake showing the steep eastern ice-contact slope (right) and the boulder-mantled distal slope (left).(C) Late Wisconsin age basal till deposits in the Sedgwick Valley, showing the chemically unweathered surfaces of boulders and compact matrix. (D) Boulder-rich till of the Late Wisconsin Rowallan Glaciation disconformably overlying strongly weathered older till of the Arm Glaciation in the upper Arm Valley.(E) Fossil alpine humus soil with dated bolster of Donatia novae-zelandiae underlying the Dante outwash fan and interstratified King River alluvial silts in the King Valley. (F) Hummocky end moraines with kettle holes deposited by the Dove and Crater lakes glaciers on the floor of Cradle Valley.

Wisconsin ice from the West Coast Range (Gibson et al. 1987, Colhoun \& Fitzsimons 1996). Thirdly, numerous dates have been obtained for the oldest organic sediments deposited in postglacial lakes and bogs within the inferred Late Wisconsin ice limits (Macphail \& Peterson 1975; table 2). These dates provide minimum ages for deglaciation.
The first radiocarbon assay of $26480 \pm 800 \mathrm{yr} \mathrm{BP}$ (W323) obtained by Gill (1956) has been found to have been obtained from derived Pliocene wood contaminated by young humic acids (Macphail et al. 1995). The date of commencement of Late Wisconsin glacial conditions is inferred from pollen-rich sediment sequences located outside 


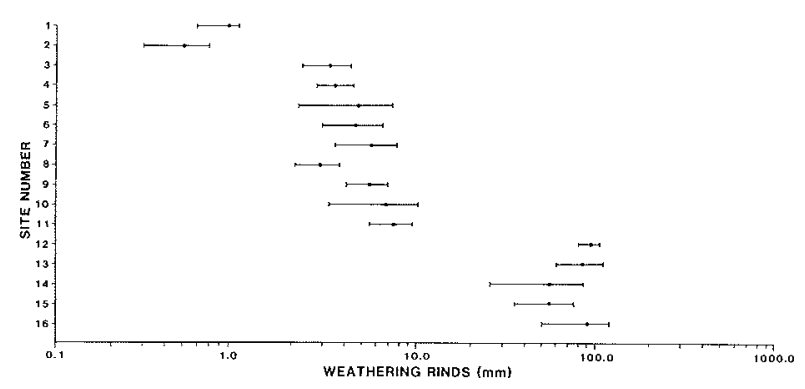

FIG. 4- Mean and standard deviation of thicknesses of dolerite weathering rinds from the central West Coast Range plotted on four-cycle semi-log base. Where possible 20 sample rinds were recorded at each site. Sites 1-2, Last Glacial Maximum; 3-11, Middle Pleistocene; 12-16, Early Pleistocene or Late Tertiary. After Kiernan (19836).

but close to the ice limits. Severe cold is indicated by maximum development of vegetation dominated by Gramineae, Asteraceae and Chenopodiaceae, and very few pollen grains of rainforest taxa. An age of 26000 25000 years is estimated from two sites in the West Coast Range: Lake Selina, which occurs $2.5 \mathrm{~km}$ north of the Rolleston end moraine (see "West Coast Range"), and Tullabardine Dam, which occurs in the Mackintosh Valley and $20 \mathrm{~km}$ north of the ice limit (Colhoun $\&$ van de Geer 1986, Colhoun et al. in press). These sites provide the best estimate for the onset of severe cold during the Late Wisconsin in Australia, as pollen analysis of sediment sequences at sites distant from ice sources are unlikely to signal as sharp a climatic change.

At Dante Rivulet in the King Valley, outwash sands and gravels deposited while ice of the West Coast Range glacial system was at its maximum extent, are interstratified with organic-rich fluvial silts deposited by the King River. These deposits overlie a humus-rich palacosol, with fossil bolsters of the alpine cushion plant Donatia novae-zelandiae (pl. 1E). A radiocarbon assay of $19100 \pm 170 \mathrm{yr}$ BP (SUA-2856) on wood fragments from the river silts within the outwash, and assays of $20100 \pm 470 \mathrm{yr} B P$ and $21180 \pm 370 \mathrm{yr} \mathrm{BP}$ (SUA-2155, SUA-2154) on the underlying Donatia bolster, indicate that the peak of the Late Wisconsin glacial stade in Tasmania was around $19 \mathrm{ka}$. This date correlates closely with dates for the maximum extent of ice during the Late Wisconsin in western New Zealand and in Chile (Suggate 1965, Suggate \& Moar 1970, Porter 1981). The date confirms the almost synchronous occurrence of the Late Wisconsin glacial maximum in southern hemisphere middle latitudes.

The oldest postglacial date was obtained from the small cirque Ooze Lake at $880 \mathrm{~m}$ altitude in southeastern Tasmania. Ice did not extend outside the cirque during the Late Wisconsin and had melted before $17700 \pm 400 \mathrm{yr}$ BP (SUA-1359) (Macphail \& Colhoun 1985), indicating that the mountains of southeastern Tasmania were only marginally glaciated. The youngest assay of $9080 \pm 200 \mathrm{yr}$ BP (I-7571) occurs at $960 \mathrm{~m}$ at Adamsons Peak, which lies $18 \mathrm{~km}$ to the northeast (Macphail 1979). The difference seems to have little bearing on the age of initial deglaciation in southeastern Tasmania, unless the Ooze lake date is erroneous.
In the West Coast Range region, the oldest postglacial date from within the ice limits is $11530 \pm 240$ yr BP (I7683) from $560 \mathrm{~m}$ altitude at Lake Vera, and the youngest $9050 \pm 120$ yr BP (SUA-1358), from $1000 \mathrm{~m}$ altitude at Tarn Shelf on the Tyndall Plateau (Macphail 1979, 1986). However, deglaciation may have commenced earlier, judging from a date of $13010 \pm 130 \mathrm{yr} \mathrm{BP}$ (SUA-2793) for the commencement of postglacial organic deposition at $180 \mathrm{~m}$ altitude, at Governor Bog in the King Valley (Colhoun et al. 1991a), and the cessation of strong frost weathering of the limestone roof of Kutikina Cave (formerly Fraser Cave) in the Franklin Valley, c. $14840 \pm 930$ yr BP (ANU-2781) (Kiernan et al. 1983). Older glacial and interglacial deposits in western Tasmania have been separated from Late Wisconsin age deposits by amino-acid dating of wood and by palaeomagnetic investigations (Colhoun \& Fitzsimons 1990, Pollington et al. 1993).

Dates of similar minimum age for deglaciation occur in north-central Tasmania and on the Central Plateau. The date of $13400 \pm 600 \mathrm{yr} \mathrm{BP}$ (SUA-2188), obtained from an infilled lake inside an end moraine at Dublin Bog, at $575 \mathrm{~m}$ altitude in the Mersey Valley, indicates retreat from the ice limits before this time (Colhoun et al. 1991b). The date of $12420 \pm 150$ yr BP (SUA-3046), from Wild Dog Creek, occurs at $1170 \mathrm{~m}$ altitude just inside the upper margin of ice that failed to override the $\mathrm{Mt}$ Jerusalem area (Hannan \& Colhoun 1991). The date indicates retreat of the upper ice margin on the western Central Plateau before $12.4 \mathrm{ka}$, while the later dates near Lake Lanka and Talinah Lagoon in the east suggest retreat of the eastern ice margin before $11 \mathrm{ka}$ (table 2, fig 2).

Several dates, taken from short sediment cores in cirque lakes in the Mt Field National Park, show that deglaciation at the highest altitudes had taken place by c. $10 \mathrm{ka}$, e.g. ages of $12960 \pm 950$ yr BP (I-7684) at Eagle Tarn, $11420 \pm 205$ yr BP (SUA-325) at Beatties Tarn and 9725 \pm 190 yr BP (I-8008) from an unnamed tarn on the Tarn Shelf (Macphail 1979). At present, no evidence has been found for a discinct Younger Dryas-type re-advance during the Late Glacial, though a block moraine with a high protalus component at $1100 \mathrm{~m}$ altitude east of Lake Newdegate could have been formed after the main deglaciation.

\section{LATE WISCONSIN ICE EXTENT AND GLACIAL LANDFORMS}

The description of glacial landforms and ice limits that follows is an updated and integrated version of detailed records for the West Coast Range Bowden (1974), Kiernan (1980), Colhoun (1985), Hammond (1985), Fitzsimons \& Colhoun 1991, and Fitzsimons et al. (1992), the northwestern Central Plateau and Mersey Valley (Hannan \& Colhoun 1987; 1991), the Forth Valley (Kiernan \& Hannan 1991), Cradle Mountain (Colhoun 1980), the Central Highlands and Lake St Clair area (Kiernan 1990a, 1991) and the Franklin Valley (Kiernan 1989). It is nor possible to show all names on the small-scale maps (figs 2, 3) of the main areas covered by ice during the Late Wisconsin, and maximum extent of ice in pre Wisconsin time. Most localities referred to are shown on the 1:100000 scale maps of the Topographic Survey of Tasmania. 
TABLE 2

Selected post-glaciation radiocarbon dates

\begin{tabular}{|c|c|c|c|c|c|}
\hline \multicolumn{2}{|c|}{ Site } & $\begin{array}{l}\text { Altitude } \\
(\mathrm{m})\end{array}$ & $\begin{array}{c}\text { Date } \\
{ }^{14} \mathrm{C} \text { yr BP }\end{array}$ & Lab no. & Source \\
\hline \multicolumn{6}{|c|}{ Western Tasmania } \\
\hline 1 & Lake Johnson & 875 & $9380 \pm 110$ & SUA-2987 & Anker (1991) \\
\hline 2 & Poets Hill & 600 & $11420 \pm 770$ & GAK-6297 & Colhoun (1992) \\
\hline 3 & Tarn Shelf, Tyndall Mens & 1000 & $9050 \pm 120$ & SUA-1358 & Macphail (1986) \\
\hline 4 & Lake Vera & 560 & $11530 \pm 240$ & $\mathrm{I}-7683$ & Macphail (1979) \\
\hline \multicolumn{6}{|c|}{ Northern Tasmania } \\
\hline 5 & Dublin Bog & 575 & $13400 \pm 600$ & SUA-2188 & Colhoun et al. (1991b) \\
\hline 6 & Lake Ayr & 870 & $11020 \pm 280$ & SUA-3060 & Wilson \& Hannan (1995) \\
\hline 7 & Lake Dove & 934 & $10620 \pm 60$ & Beta- 82244 & Dyson et al., pers. comm. \\
\hline 8 & South of Lake Lanka & 1190 & $10960 \pm 230$ & Beta-68716 & D. Hannan, pers. obs. \\
\hline 9 & North of Talinah Lagoon & 1160 & $10380 \pm 110$ & SUA-3056 & D. Hannan, pers. obs. \\
\hline 10 & Wild Dog Creek & 1170 & $12420 \pm 150$ & SUA-3046 & D. Hannan, pers. obs. \\
\hline \multicolumn{6}{|c|}{ Southern Tasmania } \\
\hline 11 & Adamsons Peak & 960 & $9080 \pm 200$ & $1-7571$ & Macphail (1979) \\
\hline 12 & Beatties Tarn & 990 & $11420 \pm 205$ & SUA-325 & Macphail (1979) \\
\hline 13 & Eagle Tarn & 1033 & $11400 \pm 235$ & $\mathrm{I}-7684$ & Macphail (1979) \\
\hline 14 & Tarn Shelf, Mt Field & 1158 & $9725 \pm 190$ & $\mathrm{I}-8008$ & Macphail (1979) \\
\hline 15 & Ooze Lake & 880 & $17700 \pm 400$ & SUA-1359 & Macphail \& Colhoun (1985) \\
\hline
\end{tabular}

\section{West Coast Range}

During the Late Wisconsin, ice accumulated on the $1000 \mathrm{~m}$ high plateau area in the central part of the Tyndall Range (fig. 2), in the cirques at the head of Tyndall Valley and occupied by Lake Huntley to the north and northeast, and in cirques east of the Bastion and Mount Geikie to the south. In addition, ice accumulated in cirques leeward of $\mathrm{Mt}$ Murchison, in the northern part of the West Coast Range, and leeward of the summits of $\mathrm{Mr}$ Owen and $\mathrm{Mt}$ Jukes, in the southern part. The extent of ice did not exceed $105 \mathrm{~km}^{2}$ (Colhoun 1985: 41). The icecap was thin, with probably no more than 50-100 m of ice cover on the upland plateau areas of the Tyndall Range and around Lake Dora. The ice attained a maximum thickness of about $250-300 \mathrm{~m}$ in the adjacent cirques and deep valleys

The icecap that accumulated on the Tyndall Range abraded the rock surface, formed small ice-eroded rock basins and moved both westwards and southeastwards. On the western side, the ice limit is marked by distinct end moraines. These extend from the plateau margin a short distance downslope into the minor valleys cut into the western scarp of the Tyndall Range (pl. 1A). To the east, ice flowed across the Lake Dora plateau towards the Eldon Valley, and southeastwards via Lake Spicer to Lake Beatrice. Several areas of fluted drift occur on the plateau, as near Farquhar Lookout. The ice margin east of Lake Dora is marked by a line of large Owen Conglomerate (Ordovician) erratics flanking a small nunatak, and the margin east of Lake Spicer by small moraines. South of Lake Beatrice, the ice margin formed an end moraine and the associated Dante outwash fan. A lateral moraine-crest extends downslope, from $800 \mathrm{~m}$ altitude on the southeastern shoulder of Mt Sedgwick to $400 \mathrm{~m}$ at the Lake Beatrice end moraine. South of Mt Sedgwick, a small glacier extended down the Sedgwick Valley to $600 \mathrm{~m}$ altitude. The limit is marked by an end moraine that shows dark grey-coloured till (pl. 1C) that has not been weathered despite containing dolerite clasts derived from Mt Sedgwick.

The ice that accumulated east of the Bastion and $\mathrm{Mt}$ Geikie flowed through Lake Margaret to the Hamilton End Moraine (pl. 1B). The ice flow scoured the basin and eroded the large rock sill at the western end of the lake, before expanding into a bipartite piedmont glacier that extended down to $550 \mathrm{~m}$ altitude on the northern side and $300 \mathrm{~m}$ on the southern. South of Lake Margaret, lateral moraines descend from $950 \mathrm{~m}$ altitude westwards to the very large end moraine, that has a crest at $640 \mathrm{~m}$ and base at $300 \mathrm{~m}$, adjacent to Lake Margaret Village. This is the highest end moraine in Australia.

North of the West Coast Range, the Tyndall Glacier flowed $2.5 \mathrm{~km}$ northwards to form a $70-100 \mathrm{~m}$ high end moraine. In the adjacent valley to the east, the Rolleston Glacier flowed $5 \mathrm{~km}$ northeastwards, from Lake Huntley cirque via the deep glacial valley occupied by Lake Rolleston, and terminated in a large complex of end moraines, south of the flat-floored Anthony outwash plain.

Further north, and leeward of Mt Murchison, two composite, deeply incised cirques were sources of southeasterly flowing glaciers. The cirques are now occupied by several tarns, the two largest being Lake Sandra and Lake Gaye. The glaciers descended steeply downslope and formed end moraines, with crests at $440 \mathrm{~m}$ altitude in the southern complex and $520 \mathrm{~m}$ in the northern.

Several other cirque and short valley glaciers occur leeward of high summits in the West Coast Range. A small cirque glacier formed at 900-1050 m altitude south of Mt Read and eroded the basin occupied by Lake Johnston. East of the southern watershed of the West Coast Range, a small steep-sided moraine occurs within the cirque southeast of 
Mt Owen. The cirque form clearly pre-dates the Late Wisconsin stage and has been occupied by ice during more than one glacial event. Similarly, two distinct moraines composed of unweathered deposits occur at the northern and southern ends of the complex of cirques that extends from Proprietary Peak to South Jukes Peak. These cirques also have a multiglacial origin (Fitzsimons et al. 1992).

The cirque, valley glacier and icecaps that formed in western Tasmania during the Late Wisconsin glacial stade were not coterminous with ice masses formed in northcentral Tasmania, at Cradle Mountain and in the upper Forth and Mersey Valley regions or in south-central Tasmania, in the Lake St Clair, upper Derwent and Franklin Valleys.

\section{North-Central Tasmania}

The maximum extent of Late Wisconsin ice in north-central Tasmania has been traced from Great Pine Tier northwest into the Mersey and Forth Valleys and the Cradle Mountain area.

Late Wisconsin ice covered $550 \mathrm{~km}^{2}$ of the Central Plateau, of which $175 \mathrm{~km}^{2}$ was north of the Great Pine Tier. The Central Plateau consists of Jurassic dolerite and is inclined southeastwards. The high western part attains approximately $1200 \mathrm{~m}$ altitude, and isolated peaks of $1400 \mathrm{~m}$ occur in the northwest. The Great Pine Tier is a 150-200 m high escarpment that extends $25 \mathrm{~km}$ southeast from the Walls of Jerusalem National Park and divides the Central Plateau into northern and southern parts. The northernmost and eastern parts of the Central Plateau were not glaciated, while in the northwest the iceflow surrounded the Walls of Jerusalem National Park (Hannan \& Colhoun 1991). A thin icecap formed near the western edge of the plateau and flowed eastwards and southeastwards. The ice eroded the strongly jointed dolerite surface to produce a multitude of roches moutonnées, whaleback ridges and rock basins now occupied by lakes (Jennings \& Ahmad 1957). To the northwest, the Mersey and Forth Valleys are deep, steep-sided and often flat-floored, and their glaciers were fed by ice from the higher surrounding plateaux (Hannan \& Colhoun 1987).

End moraines commonly mark the Late Wisconsin ice limits, but are not continuous around the former icecap. Instead, they are concentrated in certain areas, such as west of Lake Ada and east of Pillans Lake, where they form hummocky mounds. Surface boulders are abundant and often exceed $4 \mathrm{~m}$ in diameter. Moraines seldom exceed $6 \mathrm{~m}$ in height and consist of light grey, poorly-sorted cobbles and boulders in a fine matrix. Weathering rinds on subsurface clasts are less than $1 \mathrm{~mm}$ thick. There is no basal till on the eroded rocky surface of most of the glaciated area, and only small amounts have been deposited on the floors of some minor valleys near the periphery.

The Late Wisconsin ice limit has been mapped using moraines and surface boulders. These moraines are higher and have steeper slopes than older moraines, and they contain a high proportion of fine sediment. The older moraines can be devoid of fine material on the surface and may consist only of rounded dolerite boulders. Boulders inside the Late Wisconsin ice limits are rounded, entire and generally show only slight surface weathering. Those outside the limit show greater effects of exposure in the form of surface shattering, exfoliation and an accumulation of weathered material around their bases, but the limits attained by ice during earlier glaciations have not been determined in the eastern Central Plateau.

A Late Wisconsin maximum ice thickness of $80 \mathrm{~m}$ can be deduced for the northern part of the Central Plateau from the interrelationships of moraine trimlines, and the lower limits of blockfields and screes in the Turrana BluffTurrana Heights region. When the differences in altitude of the former ice margin and plateau surface are considered, they suggest the divide between west and east-flowing ice was close to the western edge of the Central Plateau, and that most ice flowed towards the east and southeast. As a result, very little ice spilled off the plateau to the northwest. This is demonstrated by the short distance that ice travelled down the Little Fisher River and by the absence of Late Wisconsin ice from the central part of the Walls of Jerusalem, west of Mt Jerusalem (Hannan \& Colhoun 1991). The thickest ice on the Central Plateau built up in the lakes Adelaide-Meston-Louisa-Myrtle area. Mt Rogoona formed a large nunatak rising above the Central Plateau icecap between lakes Myrtle and Meston. The contrast between the blocky dolerite screes on its upper slopes and the ice-moulded landscape below shows that the ice was about $200 \mathrm{~m}$ thick at Lake Myrtle. The southwestward flow of ice from this area of deeply ice-eroded valleys with ribbon lakes formed the main supply for the Mersey Glacier. Stratigraphic evidence in the Fish Valley shows that the 300-350 $\mathrm{m}$ thick Mersey Glacier reached the lower Fish Valley before the thinner ice flowing northwestwards past the Walls of Jerusalem, entered the valley head.

The Mersey Glacier comprised a reticulate system of ice fed from the Central Plateau via the Junction Lake area, Moses Creek, Lake Louisa and the Fish Valley. Ice in the Little Fisher Valley did not reach the main valley during the Late Wisconsin (Hannan \& Colhoun 1987). The main Mersey Glacier terminated in lobes at Wallace River, Lake Ayr Valley, Wurragara Creek, the upper Arm Valley, Dublin Bog, and in the Mersey Valley, near its confluence with the Arm Valley. Moraines mark the ice limits and vary from hummocky moraines at Lake Ayr (Wilson \& Hannan 1995) and lateral moraines at Wurragara Creek, to distinct end moraines at Dublin Bog and in the Mersey at the Arm Valley confluence. Around Rowallan Dam, the glacier eroded and striated the bedrock extensively. In the upper Arm Valley, dolerite till deposits of the Late Wisconsin glaciation stratigraphically overlie till of the preceding glaciation (pl. 1D), and at Rowallan Spillway, a $70 \mathrm{~m}$ section shows a Late Wisconsin sequence of unweathered sand, gravel and till deposits overlying an older sequence of more weathered deposits, that include rhythmites, sand, gravel and till. A Uranium-series assay of a thick ironpan between the two sequences of deposits gave a date of $95+80 \%$ ka (LH-1566) (P. Augustinus, pers. comm. 1995), indicating that the lower sequence is of pre-Late Wisconsin age.

During the Late Wisconsin glaciation of the Forth Valley, ice accumulated in small cirques at Mt Achilles, Mt Pelion West and Mt Thetis, and formed a $13 \mathrm{~km}$ long glacier that terminated near the junction of Oakleigh Creek, where a number of small end moraines occur (Kiernan \& Hannan 1991). At this stage there was no connection through the Lake Ayr Valley between the Mersey and Forth glacial systems (Kiernan \& Hannan 1991, Wilson \& Hannan 1995). Further north, ice that accumulated in Waterfall Valley, south of Cradle Mountain, flowed $9 \mathrm{~km}$ down the 
Hartnett Rivulet Valley. Similarly, ice that accumulated east of Cradle Mountain and ice that breached Hansons col from Lake Dove, flowed $10.5 \mathrm{~km}$ down Hansons Valley towards the Forth Valley.

North of Cradle Mountain ice accumulated in the cirques occupied by Lake Wilks and by Crater Lake. The ice from Lake Wilks flowed into Lake Dove and was over $200 \mathrm{~m}$ thick. East of Lake Dove, the summit of Mt Campbell is covered with quartzite blockfield debris and was not overridden by Late Wisconsin ice. Mr Campbell deflected the ice northwards, and the eastern trimline of the former Dove Glacier declines steeply along the western face of the mountain toward the hummocky moraines on the floor of Cradle Valley, that mark the ice limit (pl. 1F) (Colhoun 1980). West of Cradle Mountain, a small moraine bounds Suttons Tarn on the western edge of the Cradle Plateau and, north of Cradle Mountain, snow from Cradle Plateau formed a relatively large isolated cirque glacier that occupied Crater Lake. The glacier flowed northwards into Cradle Valley, where it merged with the terminal part of the Dove Glacier to the east.

\section{South-Central Tasmania}

In south-central Tasmania, the main directions of iceflow were southeast across the Central Plateau south of Great Pine Tier, southwards from sources in the Du Cane Range through the Lake Se Clair and upper Derwent Valley, and southwestwards towards the upper Franklin Valley.

Southeast of the Walls of Jerusalem, ice flowed along Powena Creek towards the gap in the Great Pine Tier, south of Lake Fanny, but did not cover the southeastern part of Great Pine Tier. Ice that formed close to the western rim of the Central Plateau between the northwestern part of Great Pine Tier and the Mountains of Jupiter flowed $10-14 \mathrm{~km}$ southeast towards ice limits which are defined by low end moraines, as at Lake Ina (Kiernan 1990b). The general southeasterly iceflow is demonstrated by the NW-SE orientation of the many ice-eroded lake basins on the plateau surface. Only in Travellers Rest Valley did the ice reach the margin of the Central Plateau, and here at least 14 moraines record retreat of the ice margin northwards (Kiernan 1985, 1991). Some of the ice formed southwest of the Mountains of Jupiter flowed southwestwards to join the Derwent Glacier that occupied the deep trough of Lake St Clair.

The main source of the Derwent Glacier lay in the Du Cane Range, where high ridges, such as Mt Geryon and The Acropolis, acted as natural snowfences to the prevailing westerly weather, leeward of which considerable volumes of ice accumulated. The largest glacier to reach Lake St Clair flowed down Narcissus Valley. Tributary glaciers flowed southeastwards along Pine, Marion and Hamilton Valleys, and became confluent with Narcissus ice. Some diffluent ice from the Mersey Glacier also passed southward through Du Cane Gap into the head of Narcissus Valley. During the maximum of the Late Wisconsin Glaciation, ice in the upper Narcissus and lower Pine Valleys was over $300 \mathrm{~m}$ thick, and the down-valley surface gradient east of Mt Olympus was $25-30 \mathrm{~m} / \mathrm{km}$. The Derwent Glacier extended to $1.2 \mathrm{~km}$ south of Lake St Clair, where it was $30 \mathrm{~km}$ distant from the Du Cane Range. At the head of
Lake St Clair, some ice spilled through the gap between $\mathrm{Mt}$ Olympus and Mt Byron into the Cuvier Valley (Kiernan 1985, 1992)

The glacial landforms in the upper Derwent Valley area result from multiple Pleistocene ice advances. Only in a few cases is it possible to ascribe erosional landforms solely to the Late Wisconsin. Cirques occur at the heads of the principal valleys and their tributaries. These are cut in Jurassic dolerite, the columnar jointing of which has produced very steep headwalls. The steepest headwalls occur where erosion has cut into the underlying Permian mudstone and sandstone, which has allowed strong basalsapping of the columns and valley-widening. The morphology of the glacial troughs varies according to rock type, valley cross-profile and thalweg gradient. Parabolic cross-profiles are most nearly attained where the troughs are cut in subhorizontally-bedded Permian sediments. The troughs tend to be narrower where the opposing walls are dolerite, and where the thalweg is steep. Lake St Clair has been deeply eroded by ice and dammed by moraines, to give a maximum depth of $167 \mathrm{~m}$ (Derbyshire 1971). The Labyrinth plateau area, west of upper Pine Valley, was icescoured by westward-flowing ice during the Late Wisconsin, which eroded many rock basins now occupied by shallow lakes such as Long Lake. During earlier glaciations, the Labyrinth was overridden by ice from the Murchison Valley that became confluent with the Derwent Glacier (Kiernan 1990b).

North of Lake St Clair, fluted drift occurs on the floor of Narcissus Valley, and moraine ridges have been deposited around the head of the lake in the area of glacial confluence. South of Lake St Clair, an impressive series of steep and narrow end moraines occurs. These moraines are generally less than $10 \mathrm{~m}$ high and are spaced $50-100 \mathrm{~m}$ apart; some can be traced for over $3 \mathrm{~km}$ (Derbyshire 1963, 1965, 1967). The steep distal slopes suggest they were formed by numerous minor re-advances rather than by gradual retreat of the glacier terminus, and the large number indicates that the glacier was very sensitive to short-term changes in mass balance. In contrast to the West Coast Range, the Derwent Glacier deposited abundant outwash sediments between the moraine ridges. The greater quantity of outwash deposits is probably due to the larger mass of ice in the southern Central Highlands than in the West Coast Range, and to greater storage of the outwash on the broad valley-plains than in the deep valleys of the west (Kiernan 1985, 1992).

During the Late Wisconsin, ice from the Derwent Glacier overflowed into the Cuvier Valley, and from there into the head of the Franklin Valley, where it merged with local ice that accumulated along the eastern slopes of the Cheyne Range from Lake Hermione to Mt Gell. The Franklin Glacier extended for $12 \mathrm{~km}$ to Lake Dixon, and constructed one large end moraine complex that contrasts with the many individual moraines formed south of Lake St Clair. Ice formed in the Mt Gell cirques flowed into the upper Franklin Valley floor at Lake Undine, where it was c. $150 \mathrm{~m}$ thick. The upper Franklin Valley is a well-developed glacial trough. It has a steep thalweg and is considerably narrower than the troughs around Lake St Clair, probably due to being cut in dolerite. Further west, individual small glaciers existed in the upper parts of valleys tributary to the Franklin River (Kiernan 1985, 1989). 
Highlands, gave values of $1050 \mathrm{~m}$ for the Mersey and $1020 \mathrm{~m}$ for the Derwent. These values are consistent with ELAs of major glaciers being lower than the regional snowline on adjacent icecaps. The $30 \mathrm{~m}$ increase in ELA between the Derwent and Mersey glaciers parallels the northward increase in regional snowline on the Central Plateau. The northward or northeastward rise in the regional snowline suggests that precipitation inputs from the southwest contributed to the much greater development of ice in the upper Derwent and Franklin Valleys than north of the Du Cane Range, in the Forth Valley-Cradle Mountain area. Comparison of the ELA levels with modern freezing levels indicates reduction of Late Wisconsin snowlines by c. $950 \mathrm{~m}$ and temperatures by around $6.2^{\circ} \mathrm{C}$, relative to present, in both the Mersey and Derwent Valleys.

The absence of Late Wisconsin ice from the surface of the Ben Lomond Plateau in northeastern Tasmania indicates that the regional snowline was above $1400 \mathrm{~m}$ (Caine 1983). At Legges Tor in the northeast, the snowline must have exceeded $1500 \mathrm{~m}$, otherwise Legges Tor would have had a small icecap. The small cirque glaciers at Denison Crag in the south, and at Hamilton Crag and Broken Bluff on the eastern scarp give ELAs of 1250-1260 m. These values, however, reflect orographically induced snowline levels, which could be as much as $300 \mathrm{~m}$ below the regional snowline.

\section{CONCLUSION}

The Late Wisconsin glaciation of Tasmania was smaller than middle and early Pleistocene glaciations of the island. Icecaps and associated outlet valley glaciers developed in two centres; the Central Plateau and adjacent mountains of the Central Highlands, and in the West Coast Range. The onset of glaciation commenced after $26-25 \mathrm{ka} \mathrm{BP}$ and peaked at $19 \mathrm{ka} \mathrm{BP}$ and all known ice had decayed before $10 \mathrm{ka} \mathrm{BP}$. The regional snowline increased in altitude across the island from below $800 \mathrm{~m}$ on the west coast to over $1500 \mathrm{~m}$ in the northeast. The large glaciers of the West Coast Range and Central Highlands and cirque glaciers of the western mountains were more active than the thin ice cap on the Central Plateau, and the isolated cirque glaciers formed leeward of mountain ranges and plateaux scarps in the east. The Late Wisconsin snowline was lowered by about $1000 \mathrm{~m}$, and mean temperature was depressed by about $6-6.5^{\circ} \mathrm{C}$ from present. The system reflects development under westerly and southerly onshore, oceanic, climatic conditions, that were modified by increasing effects of continentality inland and precipitation-shadowing by blocking mountain ranges. The blocking effects produced the unglaciated enclave of the central part of the Walls of Jerusalem National Park and the thin, relatively undynamic ice sheet of the eastern part of the Central Plateau.

\section{ACKNOWLEDGEMENTS}

This paper is Contribution No. 8 of the Geomorphology and Quaternary Science Research Unit of the Department of Geography, University of Newcastle. The authors thank Dr M.R. Banks and the referees for helpful comments on this paper.

\section{REFERENCES}

ANDREWS, J.T., 1975: GLACIAL SYSTEMS. Duxbury Press, North Scituate, Massachussetts.

ANkER, S.A., 1991: Pollen and vegetation history from Lake Johnston, in western Tasmania. Unpubl. BSc (Hons) thesis, University of Newcastle.

Augustinus, P. \& Colmoun, E.A., 1986: Glacial history of the upper Pieman and Boco valleys, western Tasmania. Aust. J. Earth Sci. 33: 181-191.

Banks, M.R. \& Ahmad, N., 1959: Notes on the Cainozoic history of western Tasmania - Malanna Glaciation. Pap. Proc. R. Soc. Tasm. 93: 117-127.

Banks, M.R., Colhoun, E.A. \& Hannan, D., 1987: Early discoverers of the effects of ice action in Australia. J. Glaciol. 33(114): 231-235.

Barbetti, M. \& Colhoun, E.A., 1988: Reversed magnetisation of glaciolacustrine sediments from western Tasmania. Search 19(3): 151-153.

BOWDEN, A.R., 1974: The glacial geomorphology of the Tyndall Mountains, western Tasmania. Unpubl. BSc (Hons) thesis, University of Tasmania

CAINE, N., 1983: THE MOUN7AINS OF NORTHEASTERN TASMANIA. Balkema, Rotterdam.

Colmoun, E.A., 1980: Glacial diversion of drainage in the Cradle Mountain National Park, Tasmania. Atust. Geogr. 14(6): 365-367.

Colhoun, E.A., 1985: Glaciations of the West Coast Range, Tasmania. Quat. Res. 24: 39-59

Colmoun, E.A., 1992: Late Glacial and Holocenc Vegetation History at Poets Hill Lake, Western Tasmania. Aust. Geogr. 23(1): 11-23.

Colhoun, E.A. \& Fitzsimons, S.J., 1990: Late Cainozoic glaciation in western Tasmania, Australia. Quat. Sci. Rev. 9: 199-216

Colmoun, E.A. \& Fitzsimons, S.J., 1996: Additional radiocarbon date from Dante outwash fan, King Valley, and dating of the Late Wisconsin glacial maximum in western Tasmania. Pap. Proc. R. Soc. Tasm. 130(1): 81-84.

Colmoun, E.A. \& van de Geer, G., 1986: Holocene to Middle Last Glaciation vegetation history at Tullabardine Dam, Western Tasmania. Proc. R. Soc. London 229B: $177-$ 207.

Colhoun, E.A., van de Geer, G. \& Fitzsmons, S.J, 1991 a: Late glacial and Holocene vegetation history at Governor Bog, King Valley, western Tasmania, Australia. J. Quat. Sci. 6(1): 55-66.

Colmoun, E.A, van de Geer, G. \& Hannan, D., 1991 b: Lace Glacial and Holocene Vegetation History at Dublin Bog, North-Central Tasmania. Aust. Geogr. Stud. 29(2): $337-$ 354.

Colhoun, E.A., Pola, J. \& Barton, C.E., in press: Late Pleistocene Vegetation and Climate History of Lake Selina, Western Tasmania. Quat. Int.

DAVIES, J.L., 1967: Tasmanian Landforms and Quaternary Climates. In Jennings, J.N. \& Mabbutt, J.A. (Eds): LANDFORM STUDIES FROM AUSTRALIA AND NEW GUINEA. Cambridge University Press: 1-25.

DAVIES, J.L., 1969: LANDFORMS OF COLD CLIMATES. ANU Press, Canberra.

Davies, J.L., 1974: Geomorphology and Quaternary environments. In Williams, W.D. (Ed.): BIOGEOGRAPHY AND ECOLOGY IN TASMANIA. Dr W. Junk, The Hague: 17-27.

Derbyshire, E., 1963: Glaciation of the Lake St Clair district, west-central Tasmania. Aust. Geogr. 9: 97-110.

DERBYSHIRE, E., 1965: The internal constitution of a Tasmanian end moraine. J. Geol. 73: 377-383.

Derbyshire, E., 1967: Glacial geomorphology and climate of the mountains of western Tasmania, with special reference 
to the north-west centre. Unpubl. PhD thesis, Monash University, Melbourne.

Derbyshire, E., 1971: A bathymetric survey of Lake St Clair. Pap. Proc. R. Soc. Tasm. 105: 49-57.

DeRbYSHiRE, E., 1972: Pleistocene glaciation of Tasmania: Review and speculations. Aust. Geogr. Stud. 10: 79-84.

Derbyshire, E.D., Banks, M.R., Davies, J.L. \& Jennings, J.N., 1965: A GLACIAL MAP OF TASMANIA. R. Soc. Tasm. Spec. Publ. 2 .

Fitzsimons, S.J. \& Colmoun, E.A., 1991: Pleistocene Glaciation of the King Valley, Western Tasmania, Australia. Quat. Res. 36: 135-156

Fitzsimons, S.J., Colhoun, E.A., van de Geer, G. \& Pollington, M.J., 1992: The Quaternary geology and glaciation of the King Valley, western Tasmania. Geol. Surv. Tasm. Bull. 68: 1-56.

Galloway, R.W., 1965: Late Quaternary Climates in Australia. J. Geol. 73: 603-617.

Gibson, N., Kiernan, K.W. \& Macphall, M.K., 1987: A fossil bolster plant from the King River, Tasmania, Pap. Proc. R. Soc. Tasm. 121:35-42.

GIL., E.D., 1956: Radiocarbon dating for glacial varves in Tasmania. Azust. J. Sci. 19: 80.

GREgoRY, J.W., 1904: A contribution to the glacial geology of Tasmania. Q. J. Geol. Soc. London 60: 37-53.

HAMmOND, A., 1985: Soils and glacial geomorphology of the central West Coast Range, Tasmania. Unpubl. Hons thesis, University of Tasmania.

Hannan, D.G. \& Colhoun, E.A., 1987: Glacial Stratigraphy of the Upper Mersey Valley, Tasmania. Aust. Geogr. Stud. 25(2): 36-46.

Hannan, D.G. \& Colhoun, E.A., 1991: When were the Walls of Jerusalem last glaciated? Pap. Proc. R. Soc. Tasm. 125: $1-6$.

Jennings, J.N. \& Ahmad, N., 1957: The Legacy of an ice cap. Aust. Geogr. 7: 62-75.

Jennings, J.N. \& BAnks M.R., 1958: The Pleistocene glacial history of Tasmania. J. Glaciol. 3(24): 298-303.

Kiernan, K.W., 1980: Pleistocene glaciation of the central West Coast Range, Tasmania. Unpubl. Hons thesis, University of Tasmania.

KIERNAN, K.W., 1982: Glaciation and karst in Tasmania: Review and speculations. Helictite 20(1): 11-16.

KIERNAN, K.W., 1983a: Weathering evidence for an additional glacial stage in Tasmania. Aust. Geogr. Stud. 21: 197220 .

KIERNAN, K.W., 1983b: Relationship of cave fills to glaciation in the Nelson River valley, central western Tasmania. Aust. Geogr. 15(6): 367-375.

Kiernan, K.W., 1985: Late Cainozoic glaciation and mountain geomorphology in the Central Highlands of Tasmania. Unpubl. PhD thesis, 2 vols, University of Tasmania, Hobart.

KIERNAN, K.W., 1987: A GEOMORPHOLOGICAL RECONNAISSANCE OF THE SOUTHERN FORESTS AREA, TASMANIA. Anutech Pty Ltd, Canberra: $49 \mathrm{pp}$.

KiERNAN, K.W., 1989: Multiple glaciation of the upper Franklin Valley, Western Tasmania Wilderness World Heritage Area. Aust. Geogr. Stud. 27: 208-233.

Kiernan, K.W., 1990a: The alpine geomorphology of the Mt. Anne massif, southwestern Tasmania. Aust. Geogr. 21(2): 113-125.

Kiernan, K.W., 1990b: The extent of late Cainozoic glaciation in the Central Highlands of Tasmania. Arct. Alp. Res. 22(4): 341-354.

Kiernan, K.W., 1991: Glacial history of the upper Derwent River Valley, Tasmania. NZ J. Geol. Geophys. 34: 157166.
Kiernan, K.W., 1992: Mountain geomorphology and the Last Glaciation at Lake St Clair. Pap. Proc. R. Soc. Tasm. 126: $47-57$.

KIERNAN, K.W., 1995: A reconnaissance of the geomorphology and glacial history of the upper Gordon River Valley, Tasmania. Tasforests 7: 51-76.

Kiernan, K.W. \& HANNAN, D.G., 1991: Glaciation of the upper Forth River catchment, Tasmania. Aust. Geogr. Stud. 29(1): 155-173.

Kiernan, K.W., Jones, R. \& Ranson, D., 1983: New evidence from Fraser Cave for glacial age man in south-west Tasmania. Nature 301: 28-32.

LEwIS, A.N., 1945: Pleistocene Glaciation in Tasmania. Pap. Proc. R. Soc. Tasm. (1944): 41-56.

Mackintosh, A., 1993: Late Quaternary glaciation of Mt Field Plateau, southern Tasmania. Unpubl. BSc (Hons) thesis, Department of Geology, University of Newcastle, NSW.

MACPHAIL, M.K., 1979: Vegetation and climates in southern Tasmania since the Last Glaciation. Quat. Res. 11:306341.

Macphall, M.K., 1986: "Over the top": Pollen-based reconstructions of past alpine floras and vegetation in Tasmania. In Barlow, B.A. (Ed.): FLORA AND FAUNA OF ALPINE AUSTRALASIA. AGES AND ORIGINS. CSIRO, Melbourne: 173-204.

Macphail, M.K. \& Colhoun, E.A., 1985: Late Last Glacial vegetation, climates and fire activity in southwest Tasmania. Search 16 (1-2): 43-45.

Macphail, M.K., Colhoun, E.A. \& Fitzsimons, S.J., 1995: Key periods in the evolution of the Cenozoic vegetation and flora in western Tasmania: the Late Pliocene. Aust. J. Bot. 43: 505-526.

Macphall, M.K. \& Peterson, J.A., 1975: New deglaciation dates from Tasmania. Search 6: 127-130.

Meierding, T.C., 1982: Late Pleistocene glacial equilibrium-line altitudes in the Colorado Front Range: A comparison of methods. Quat. Res. 18: 289-310.

Nunez, M. \& Colhoun, E.A., 1986: A note on air temperature lapse rates on Mount Wellington. Pap. Proc. $R$. Soc. Tasm. 120: 11-15.

Paterson, W.S.B., 1981: THE PHYSICS OF GLACIERS. 2nd edn. Pergamon Press.

Peterson, J.A., 1966: Glaciation of the Frenchmans Cap National Park. Pap. Proc. R. Soc. Tasm. 100: 117-129.

Peterson, J.A., 1968: Cirque morphology and pleistocene ice formation conditions in southeastern Australia. Aust. Geogr. Stud. 6: 67-83.

Peterson, J.A. \& Robinson, G., 1969: Trend surface mapping of cirque floor levels. Nature 222: 75-76.

Pollington, M.J., Colhoun, E.A. \& Barton, C.E., 1993: Palaeomagnetic constraints on the ages of Tasmanian glaciations. Explor. Geophys. 24: 305-310.

PORTER, S.C., 1975: Equilibrium-line altitudes of Late Quaternary glaciers in the Southern Alps, New Zealand. Quat. Res. 5: $27-47$.

PORTER, S.C., 1981: Pleistocene glaciation in the Southern Lake District of Chile. Quat. Res. 16: 263-292.

Suggate, R.P., 1965: Late Pleistocene geology of the northern part of South Island, New Zealand. NZ Dep. Sci. Ind. Res. Bull. 77.

Suggate, R.P. \& Moar, N., 1970: Revision of the chronology of the late Otira Glacial. NZ J. Geol. Geophys. 13: 742746.

WILson, R.J.S. \& Hannan, D.G., 1995: From ice to ice free: glaciation of the Lake Ayr Valley, central Tasmania. Pap. Proc. R. Soc. Tasm. 129: 35-41.

(accepted 14 May 1996) 
